\title{
PENINGKATAN HASIL BELAJAR IPA KONSEP SIFAT-SIFAT CAHAYA MELALUI METODE EKSPERIMEN PADA MURID KELAS IV SDI GARAUPA KECAMATAN PASILAMBENA KABUPATEN SELAYAR
}

\author{
Husnaeni, Ernawati, Andi Marliah Bakri \\ Pendidikan Guru Sekolah Dasar, Fakultas Keguruan dan Ilmu Pendidikan \\ Universitas Muhammadiyah Makassar \\ Iqramsyar34@gmail.com
}

\begin{abstract}
ABSTRAK
Masalah utama dalam penelitian ini yaitu apakah melalui metode eksperimen dapat meningkatkan hasil belajar IPA Konsep Sifat-Sifat Cahaya pada Murid Kelas IV SDI Garaupa Kecamatan Pasilambena Kabupaten Selayar. Penelitian ini bertujuan untuk mengetahui peningkatan hasil belajar IPA melalui metode eksperimen pada proses belajar mengajar murid kelas IV SDI Garaupa Kecamatan Pasilambena Kabupaten Selayar. Jenis penelitian ini adalah penelitian tindakan kelas (class action research) yang terdiri dari dua siklus dimana setiap siklus dilaksanakan sebanyak tiga kali pertemuan. Prosedur penelitian ini meliputi perencanaan, pelaksanaan tindakan, observasi dan refleksi. Subjek dalam penelitian ini adalah murid kelas IV SDI Garaupa Kecamatan Pasilambena Kabupaten Selayar sebanyak 25 orang. Hasil penelitian ini menunjukkan bahwa pada siklus I nilai rata-rata yang diperoleh murid adalah 68,33 dari 100 nilai yang mungkin dicapai, dan setelah dikelompokkan dalam 5 kategori terlihat bahwa dari 24 orang murid yang menjadi sampel penelitian yang memiliki hasil belajar IPA yang dikategorikan rendah sebanyak 11 orang atau sekitar $45,84 \%$, yang dikategorikan sedang 0 orang murid atau sekitar $00,00 \%$, yang dikategorikan tinggi 9 orang murid atau sekitar 37,5\% dan terdapat yang memiliki nilai sangat tinggi 4 orang murid atau $16,66 \%$. Sedangkan pada siklus II , nilai rata-rata murid meningkat menjadi 79,33 dan setelah dikelompokkan dalam 5 kategori ternyata dari 24 orang kelas IV SDI N0. 8 Garaupa yang menjadi sampel penelitian tidak ada seorang pun murid yang memperoleh nilai yang dikategorikan sangat rendah. Pada kategori sangat tinggi dan kategori tinggi terdapat masing-masing 12 orang murid atau sekitar $50 \%$. Pada kategori sedang terdapat 0 murid atau $0 \%$, pada kategori rendah dan sangat 0 murid atau $0 \%$. Setelah dikategorisasikan ke dalam lima kategori, diketahui bahwa tingkat penguasaan kelas IV SDI No. 8 Garaupa Kecamatan Pasilambena Kabupaten Kepulauan Selayar pada siklus II berada dalam kategori sangat tinggi. Setelah pelaksanaan siklus II meningkat dengan kategori sangat tinggi dan rata-rata hasil belajar murid meningkat. Berdasarkan hasil penelitian tersebut diatas, dapat disimpulkan hasil belajar IPA murid kleas IV SDI Garaupa Kecamatan Pasilambena Kabupaten Selayar melalui penerapan metode eksperimen mengalami peningkatan.
\end{abstract}

Kata kunci: Peningkatan, Hasil Belajar, Metode Eksperimen, dan Konnsep Sifat- Sifat Cahaya 


\section{PENDAHULUAN}

Tujuan pembelajaran IPA di sekolah dasar adalah mengembangkan sikap dan keterampilan serta kemampuan untuk meningkatkan pengetahuan dan berpikir kritis.Hal ini sesuai pandangan Carin, (Khaeruddin, 2005:

11) mengemukakan bahwa: pada dasarnya tujuan IPA di sekolah sebagai institusi sosial yang diadopsi dari pusat nasional pembangunan pendidikan sains adalah: (1)menambah keingin tahuan, (2) mengembangkan keterampilan menginvestigasi, dan (3) Sains, teknologi, dan masyarakat.Selain itu, Pada tingkat SD mata pelajaran IPA juga merupakan salah satu program pembelajaran yang bertujuan untuk memperkenalkan dasar-dasar dari perkembangan ilmu pengetahuan dan teknologi sejak dini pada siswa dan untuk membina serta menyiapkan siswa agar nantinya mampu dan tanggap dalam menghadapi lingkungannya.

Pengembangan pemahaman siswa merupakan salah satu upaya yang harus dilakukan dalam pembelajaran. Hal ini sejalan dengan pendapat Dimyati (2006: 96) mengemukakan bahwa upaya yang dapat dilakukan untuk meningkatkan kualitas pembelajaran dalam implementasi KTSP adalah peningkatan aktivitas dan pemahaman siswa melalui berbagai interaksi dan pengalaman belajar dalam meningkatkan kemampuan kognitif, afektif, dan psikomotorik.

Sejalan dengan hal itu, pada dasarnya pembelajaran IPA di sekolah dasar adalah untuk membentuk dan mengembangkan kognitif, afektif, psikomotor, kreativitas serta melatih siswa berfikir kritis dalam mengaktualisasikan diri memahami fenomena-fenomena alam yang ada dilingkungannya, sehingga nantinya siswa dapat menghadapi tantangan hidup yang semakin kompetitif serta mampu menyesuaikan diri dengan perubahan-perubahan yang akan terjadi di lingkungan sekitarnya. Disamping pengembangan kognitif, afektif, dan psikomotor pengembangan kreativitas juga menjadi penekanan dalam pembelajaran IPA, dengan kreativitasnya siswa dapat mengelola dan mengkonstruksi pemikirannya sendiri, menghubungkan antara satu fenomena dengan fenomena lain 
sehingga memperoleh suatu pemahaman terhadap realitas fisik.

Dalam suasana belajar mengajar IPA di sekolah-sekolah dijumpai masalah, yaitu siswa mendapatkan nilai tinggi, namun mereka kurang mampu menerapkan pemerolehannya, baik berupa pengetahuan, keterampilan, maupun sikap dalam kehidupan nyata. Hal ini disebabkan karena materi pelajaran IPA diterima melalui informasi verbal. Mereka tidak dibiasakan aktif mencoba sendiri pengetahuan atau informasi itu dalam kehidupan nyata.

Berdasarkan permasalahan kenyataan diatas, maka peneliti tertarik untuk melakukan suatu penilitian tindakan kelas (PTK) dengan menggunakan metode eksperimen sesuai dengan judul yang yang diangkat yaitu,"Peningkatkan hasil belajar IPA Konsep Sifat-Sifat Cahaya melalui Metode Eksperimen pada murid kelas IV SDI Garaupa Kecamatan Pasilambena Kabupaten Selayar" Berdasarkan latar belakang masalah yang telah dikemukakan,maka permasalahan dalam penelitian ini dirumuskan sebagai berikut Apakah hasil belajar konsep sifat-sifat cahaya dapat ditingkatkan melalui metode eksperimen, Bagaimana hasil belajar konsep sifat-sifat cahaya setelah menggunakan metode ekperimen

\section{Sifat-sifat cahaya}

Haryanto membagi sifat-sifat cahaya menjadi empat, yaitu cahaya merambat lurus, dapat dibiaskan, dapat dipantulkan, menembus benda bening.Cahaya Merambat Lurus Cahaya memancar kesegala arah dengan arah rambat lurus (terjadi pada medium yang dilalui serba sama disemua bagiannya). Dalam kehidupan sehari-hari sering kita lihat cahaya merambat lurus. Misalnya pada percobaan pada gambar dibawah ini Cahaya dapat dibiaskan Pembiasan (refraksi) adalah peristiwa pembelokan arah rambatcahaya pada bidang batas antara dua medium yang kerapatannya berbeda. Pembiasan disebabkan oleh cepat rambat cahaya yang berbedabeda untuk tiap medium yang jenisnya berbedabeda.Hukum Snellius menyatakan bahwa. sinar datang, garis normal, dan sinar bias terletak dalam satu bidang datar perbandingan antara proyeksi sinar datang dengan proyeksi sinar bias pada bidang batas 
merupakan bilangan tetap yang disebut indeks bias.Cahaya dapat dipantulkanMenurut Snellius Hukum pemantulan cahaya sebagai berikut: Berkas sinar datang, garis normal dan berkas sinar pantul, terletak pada sebuah bidang datar. Sudut datang selalu sama dengan sudut pantul.Cahaya menembus benda bening Benda yang dapat ditembus cahaya disebut benda bening

\section{Metode Eksperimen}

Eksperimen

merupakan

metode mengajar yang sangat efektif dalam menolong murid mencari jawaban atas pertanyaan seperti : Bagaimana cara membuatnya? Terdiri dari bahan apa? Cara mana yang paling baik?Bagaimana diketahui kebenarannya?

Demonstrasi sebagai metode mengajar dimaksudkan bahwa seorang guru, orang luar yang sengaja rninta, atau murid sekalipun memperlihatkan pada seluruh kelas suatu proses, misalnya bagaimana cara bekerjanya sebuah alat pencuci pakaian yang otomatis.Dengan eksperimen dimaksudkan bahwa guru atau murid mencoba mengerjakan sesuatu serta mengamati proses dan hasil proses itu. Dengan eksperimen kita bisa memperoleh jawaban tentang : Bagaimana kita tahu bahwa itu benar? Cara manakah yang merupakan cara terbaik ? Apakah yang akan terjadi ? Terjadi dari bahan apa ?Di dalam pelaksanaanya metode eksperimen dapat dirangkaikan dengan demonstrasi.

$\begin{array}{cc}\text { Metode } & \text { eksperimen } \\ \text { dilakukan dengan memberikan }\end{array}$
treatment (perlakuan) yang berbeda pada setiap grup sampel,dengan adanya treatment yang berbeda, maka reaksi yang terjadi akan berbeda..jadi inti dari metode eksperimen adalah "what if"= apa yang terjadi apabila dilakukan perubahan pada setiap grup sampel. Berdasarkan analogi dari jawaban yang sudah ada, thomas alfa edison melakukan treatment yang berbedabeda pada kondisi sampel yang ada.

\section{Hasil Belajar}

Belajar merupakan istilah yang akrab dan sekaligus sering dilakukan oleh kita semua. Belajar merupakan kunci keberhasilan dan kesuksesan dalam hal apa pun dan bidang apa pun. Wajar ketika ada 
orang mengatakan "kalau ingin berhasil dan sukses maka harus belajar". Perkataan ini sangat rasional mengingat pengertian belajar secara sederhana dapat diartikan sebagai perubahan perilaku dari tidak tahu menjadi tahu (Semiawan , 1998).

Gage 1984 (Sagala, 2011: 13) mengartikan belajar sebagai suatu proses dimana organisma berubah perilakunya sebagai akibat dari pengalaman. Sejalan dengan itu, Thursan (Munawar, 2009) mengatakan bahwa belajar adalah suatu proses perubahan di dalam kepribadian manusia, dan perubahan tersebut ditampakkan dalam bentuk peningkatan kualitas dan kuantitas tingkah laku seperti peningkatan kecakapan, pengetahuan, sikap, kebiasaan, pemahaman, dan keterampilan, serta pola piker.

Gagne (Dimyati dan Mudjino, 2006: 10) berpendapat bahwa belajar merupakan kegiatan yang kompleks.Hasil belajar merupakan kapabilitas. Setelah belajar orang akan memiliki keterampilan, pengetahuan, sikap dan nilai.

Dari beberapa pengertian belajar di atas, dapat ditarik satu kesimpulan bahwa belajar merupakan suatu kegiatan yang dilakukan secara sadar yang mengakibatkan terjadinya perubahan tinglkah laku.Perlu diingat tidak semua perubahan tingkah laku merupakan hasil belajar seperti perubahan akibat minuman keras (mabuk), kecelakaan dan lain-lain. Tetapi yang termasuk perubahan dalam belajar adalah (1) perubahan yang disadari atau dilakukan dengan sengaja; (2) perubahannya berkelanjutan; (3) perubahan bersifat positif dan aktif; (4) perubahannya bersifat permanen, bertujuan dan terarah.

\section{METODE PENELITIAN}

Penelitian yang digunakan adalah penelitian tindakan kelas (PTK) yang melibatkan penelitian berulang-ulang untuk memperbaiki dan meningkatkan kualitas pembelajaran dan hasil belajar siswa dengan melakukan tindakan tertentu.

Terdapat beberapa macam model PTK, namun yang akan dipilih dalam penelitian ini adalah Metode Eksperimen pada peningkatan belajar IPA. Model ini terdiri dari empat komponen dalam satu siklus yaitu, (1) Perencanaan, (2) Tindakan, (3) 
Observasi, (4) Refleksi. Dari ke empat komponen tersebut dilaksanakan secara berurutan dalam dua siklus. Penelitian tindakan kelas ditujukan sebagai perbaikan atas hasil refleksi terhadap tindakan sebelumnya yang dianggap belum berhasil.

\section{HASIL PENELITIAN DAN PEMBAHASAN}

Berdasarkan hasil analisis atau pelaksanaan siklus I, maka secara deskriptif hasil penelitian ini mengungkapkan bahwa setelah pelaksanaan tindakan siklus I, nilai rata-rata yang diperoleh murid adalah 68,33 dari 100 nilai yang mungkin dicapai, dan setelah dikelompokkan dalam 5 kategori terlihat bahwa dari 24 orang murid yang menjadi sampel penelitian yang memiliki hasil belajar IPA yang dikategorikan rendah sebanyak 11 orang atau sekitar45,84\%, yang dikategorikan sedang 0 orang murid atau sekitar 00,00\%, yang dikategorikan tinggi 9 orang murid atau sekitar 37,5\% dan terdapat yang memiliki nilai sangat tinggi 4 orang murid atau 16,66\%. Setelah dikategorisasikan ke dalam lima kategori, diketahui bahwa tingkat penguasaan kelas IV SDI No. 8 Garaupa KecamatanPasilambena Kabupaten Kepulauan Selayar pada siklus I berada dalam kategori sedang.

Selama pelaksanaan siklus I dengan Kehadiran murid pada siklus I sebesar 75\%.Hal ini berarti bahwa motivasi dan minat belajar IPAmurid cukup besar. Persentase murid yang membuat catatan pada saat proses pembelajaran sebesar $25 \%$ pada siklus I. Persentase murid menunjukan pertanyaan kepada guru adalah 25\% pada siklus I. Ini berarti bahwa masih sedikit murid yang mengerti dengan materi yang diajarkan. Murid yang memberikan penjelasan kepada temannya pada saat diskusi dalam kelompok adalah $50 \%$ pada siklus I . Persentase murid yang mendengarkan penjelasan pada saat guru menyajikan materi meningkat dari $50 \%$ pada siklus I. Pada siklus I murid yang melakukan kegiatan lain sebesar 50\%.

Sedangkan hasil observasi yang dilakukan pada guru adalah mereka belum mampu menyusun materi pelajaran, guru kemudian menyampaikan tujuan pembelajarn khusus. Sebelum pelajaran di mulai, 
guru tidak memberikan tes awal pada murid. Selain itu, guru juga tidak menyediakan kondisi belajar (media pembelajaran).

Pada umumnya murid hanya mengikuti kegiatan seperti pembelajaran sebelumnya, yakni hanya mendengar dan mencatat pelajaran yang diberikan tanpa ada inisiatif untuk mengajukan pertanyaan maupun tanggapan, melihat keadaan demikian murid yang tidak aktif dimotivasi dan diarahkan sedemikian hingga berani menjawab soal-soal yang diberikan.

Berdasarkan hasil refleksi pelaksanaan siklus I, maka pada pelaksanaan siklus II direkomendasikan beberapa hal sebagai bahan penyempurnaan yang dimaksudkan tersebut diantaranya: (1) mengidentifikasikan pelaksanaan penggunaan metode eksperimen pada proses belajar, (2) mengurangi atau menghindari perilaku murid yang sempat menganggu pelaksanaan proses belajar mengajar, dan (3) melaksanakan secara intensif indikator pembelajaran dalam pelaksanaan proses belajar mengajar.

Berdasarkan hasil analisis data yang telah diuraikan di atas, maka secara deskriptif menunjukkan bahwa setelah pelaksanaan tindakan siklus II, nilai rata-rata murid meningkat menjadi 79,33 dan setelah dikelompokkan dalam 5 kategori ternyata dari 24 orang kelas IV SDI N0. 8 Garaupa yang menjadi sampel penelitian tidak ada seorang pun murid yang memperoleh nilai yang dikategorikan sangat rendah. Pada kategorisangat tinggi dan kategori tinggi terdapat masing-masing 12orang murid atau sekitar 50\%. Pada kategori sedang terdapat 0 murid atau $0 \%$, pada kategori rendah dan sangat 0 murid atau $0 \%$. Setelah dikategorisasikan ke dalam lima kategori, diketahui bahwa tingkat penguasaan kelas IV SDI No. 8 Garaupa Kecamatan Pasilambena Kabupaten Kepulauan Selayar pada siklus II berada dalam kategorisangat tinggi. Setelah pelaksanaan siklus II meningkat dengan kategori sangat tinggi dan rata-rata hasil belajar murid meningkat.

Berdasarkan pengamatan tingkah laku murid, maka secara deskriptif diungkapkan bahwa persentase murid yang terlibat aktif dalam proses belajar mengajar mengalami peningkatan. Hal ini 
berdasarkan Kehadiran murid pada siklus I ke siklus II mengalami peningkatan.Pada siklus II mencapai 100\%.Hal ini berarti bahwa motivasi dan minat belajar IPA murid semakin tinggi. Persentase murid yang membuat catatan pada saat proses pembelajaran meningkat menjadi 75\% pada siklus II. Persentase murid menunjukan pertanyaan kepada guru adalah 50\% pada siklus II.Ini berarti bahwa semakin banyak murid yang sudah mengerti materi yang diberikan.Murid yang memberikan penjelasan kepada temannya pada saat diskusi dalam kelompok menjadi 50\% pada siklus II. Persentase murid yang mendengarkan penjelasan pada saat guru menyajikan materi meningkat menjadi $75 \%$ pada siklus II. Pada siklus ini murid yang melakukan kegiatan lain pada siklus II berkurang menjadi 25\%.

Sedangkan hasil observasi yang dilakukan pada guru di siklus II adalah guru telah menyusun materi pelajaran, guru kemudian menyampaikan tujuan pembelajarn khusus. Sebelum pelajaran di mulai, guru memberikan tes awal pada murid untuk mengetahui sejauh mana kemampuan murid. Selain itu, guru menyediakan media pembelajaran.

Dari hasil analisis deskriptif di atas, hasil belajar murid sudah meningkat setelah tindakan siklus berikutnya yaitu dari skor rata-rata $68,33 \%$ menjadi 79,33 .

Berdasarkan hasil penelitian tersebut, dapat dinyatakan bahwa penggunaan metode eksperimen dalam pembelajarandapat meningkatkan hasil belajar IPA murid kelas IV SDINo. 8 Garaupa Kecamatan Pasilambena Kabupaten Kepulauan Selayar. Peningkatan yang sangat signifikan terjadi setelah diberikan perlakuan yang sama pada dua siklus. Penggunaan metde eksperimen dalam pembelajaran juga terbukti dapat meningkatkan motivasi murid untuk mengikuti proses belajar mengajar, hal ini terlihat pada antusias murid untuk hadir serta berpartisipasi selama proses pembelajaran berlangsung.

$$
\text { Penerapan }
$$

metode eksperimen dalam pembelajaran dapat menarik perhatian murid karena guru dalam proses belajar mengajar tidak membuat kelas menjadi kaku, akan tetapi guru mengajak murid untuk belajar sambil 
bermain. Murid kelas IV SDI No. 8 Garaupa yang pada dasarnya mereka berada pada usia anak-anak sudah pasti menyukai model pembelajaran yang menyenangkan, salah satu metode pembelajaran yang menyenangkan bagi anak adalah dengan menggunakan metode eksperimen. Metode ini ternyata mampu meningkatkan hasil belajar IPA murid kelas IV SDI No. 8Garaupa Kecamatan Pasilambena Kabupaten Kepulauan Selayar.

\section{KESIMPULAN DAN SARAN}

Simpulan yang dapat dirangkum dari hasil penelitian tindakan kelas yang telah dilakukan selama dua siklus adalah hasil belajar IPAsetelah menggunakan metode eksperimen pada pembelajaran IPA pada siklus I berada dalam kategori sedang dengan skor rata-rata $68,33 \%$. Sedangkan pada siklus II berada dalkategori sangat tinggi dengan skor rata-rata 79,16 Dengan demikian melalui penggunaan metode eksperimen pada pembelajaran IPAdapat meningkatkan hasil belajar IPAkelas IV SDI No. 8 Garaupa Kecamatan Pasilambena Kabupaten Kepulauan Selayar.
Berdasarkan uraian dan kesimpulan, beberapa saran-saran berikut layak untuk diperhatikan: Kepada guru khususnya guru mata pelajaran IPAdisarankan agar di dalam proses belajar mengajar hendaknya memberikan perhatian semaksimal mungkin kepada murid dengan cara memberikan teguran langsung yang membuat mereka termotivasi untuk belajar.2. Untuk meningkatkan hasil belajar IPAharus dilibatkan dalam proses pembelajaran sehingga tercipta kemandirian untuk menyelesaikan soal di rumah tentang materi yang telah dipelajari dan materi yang akan dipelajari selanjutnya, sehingga penggunaan metode eksperimen pada proses belajar mengajar merupakan salah satu metode alternatif. Diharapkan kepada peneliti lain dalam bidang kependidikan dapat meneliti lebih lanjut tentg cara atau metode yang relatif dan efisien untuk mengatasi kesulitan murid dalam mempelajari IPA.

\section{DAFTAR PUSTAKA}

Dimyanti. 2006. Belajar Dan Pembelajaran. Jakarta: Rineka Cipta 
Depdiknas. 1999. Kurikulum Tingkat SatuanPendidikan (KTSP) Mata Pelajaran SAINS SD/MI. Jakarta: Depdiknas

Kamara, Dkk. 2002.Strategi Belajar Tuntas. Dep. Pendidikandan Kebudayaan. Snjarindo. Sulawesi Selatan

Khaeruddindan Sujiono, E. H. 2005. Pembelajaran Sains (IPA) Berdasarkan Kurikulum Berbasis Kompetensi.Makassar : BadanPenerbit Makassar

Muslich Masnur.2010. Penelitian Tindakan Kelas itu Mudah. Jakarta: Bumi Aksara

Muhibbin. 2008. Meningkatkan Hasil Belajar IPA Melalui Strategi Belajar Tuntas Siswa Kelas VII SMP Negeri 2 Sungguminasa Kabupaten Gowa. Skripsi. FIP Universitas Negeri Makassar

Slameto. 2003. Belajardan Faktorfaktor yang Mempengaruhinya. Jakarta: RinekaCipta.

SumatowaUsman. 2006. Bagaimanapembelajaran IPA di SD. Jakarta :Depdikbud. DirektoratDikti

Suryabrata, Sumardi. 1984. Psikologi Pendidkan. Jakarta. Armico

TiroArif M. 2004.Dasar-dasar Statistik.Makassar: Andira Publisher

Vessel, M.F. 1965.Elementary School Science Teaching. New Delhi: Pentice-Hall of India, Ltd.
Asmani Jamal Ma'mur. 2011. Penelitian Tindakan Kelas. Jakarta : Laksana

Administrasi Tata Usaha. SDI No. 8 Garaupa Kematan Pasilambena Kabupaten Kepulaun Selayat. 